\title{
Aplikasi Android Sebaran Lokasi UMKM di Kota Bogor Dengan Formula Haversine
}

\author{
Safaruddin Hidayat Al Ikhsan ${ }^{1}$, Fety Fatimah ${ }^{2}$, Riyan Saputra Irawan ${ }^{3}$ \\ 1,2,3 Program Studi Teknik Informatika, Universitas Ibn Khaldun Bogor, Indonesia \\ Email: safaruddin@ft.uika-bogor.ac.id
}

\begin{abstract}
Abstrak
Saat ini banyak bermunculan beragam usaha mikro di berbagai wilayah di Indonesia, tidak terkecuali di Kota Bogor. Pada umumnya, usaha mikro ini berlokasi di lingkungan padat penduduk atau industri rumahan, sehingga keberadaan lokasi usaha mikro tersebut menjadi kurang diketahui masyarakat luas. Oleh karena itu, diperlukan suatu media yang dapat digunakan oleh masyarakat untuk mengetahui jasa apa saja yang ada di sekitarnya sesuai kebutuhan. Penelitian ini bertujuan untuk menerapkan Metode Location Based Services (LBS) dan Formula Haversine dalam pembuatan aplikasi sebaran lokasi jasa UMKM berbasis Android. Metode LBS digunakan untuk menentukan lokasi pengguna aplikasi dengan memanfaatkan teknologi GPS pada smartphone, sedangkan Formula Haversine digunakan untuk mengukur jarak pengguna aplikasi terhadap lokasi suatu jasa. Tahapan yang dilaksanakan pada penelitian ini terdiri dari pengumpulan data, analisis, perancangan, pembuatan program aplikasi, dan pengujian terhadap operasionalitas aplikasi yang dilakukan dengan Metode Black Box. Data yang digunakan pada penelitian ini didapatkan dari hasil observasi terhadap beberapa sampel jasa UMKM yang ada di Kota Bogor. Hasil dari penelitian ini adalah sebuah aplikasi sebaran lokasi jasa UMKM di Kota Bogor berbasis Android yang dapat dipergunakan oleh masyarakat sebagai pengguna aplikasi untuk melihat sebaran lokasi jasa di Kota Bogor.
\end{abstract}

Kata kunci: Usaha Mikro; UMKM; Android; LBS; Haversine

\begin{abstract}
Today, many diverse micro businesses have sprung up in various regions in Indonesia, including the City of Bogor. In general, microbusinesses are located in densely populated environments or home industries, so the existence of these microbusiness locations is less known to the wider community. Therefore, we need a media that can be used by the community to find out what services are around it as needed. This study aims to apply the Location Based Services (LBS) Method and Haversine Formula in making Android-based UMKM service location distribution applications. The LBS method is used to determine the location of application users by utilizing GPS technology on smartphones, while the Formula Haversine is used to measure the distance of application users to the location of a service. The stages carried out in this study consisted of collecting data, analyzing, designing, making application programs, and testing the operationality of applications carried out by the Black Box Method. The data used in this study were obtained from observations of several samples of MSME services in Bogor City. The result of this study is an application of the distribution of MSME service locations in Bogor based on Android that can be used by the public as application users to view the distribution of service locations in Bogor.
\end{abstract}


Keywords: UMKM; Android; LBS; Haversine; Micro Bussiness

\section{PENDAHULUAN}

Usaha Mikro, Kecil dan Menengah (UMKM) memiliki peran yang sangat penting dan strategis dalam pembangunan ekonomi nasional, penyerapan tenaga kerja dan pendistribusian hasil pembangunan. Jumlah pengusaha Indonesia pada tahun 2012 sebanyak 56.539 .560 unit, dimana komposisi UMKM adalah sebanyak 56.534 .592 unit atau 99.99\% sedangkan 4.968 unit atau $0,01 \%$ sisanya adalah usaha besar. Perkembangan UMKM sektor ekonomi bidang penyediaan jasa-jasa memiliki perkembangan yang cukup baik, namun masih berada jauh di bawah jenis klasifikasi bidang UMKM sektor ekonomi lainnya. Statistik yang dihimpun oleh Bank Indonesia menghasilkan data UMKM sektor ekonomi yang memiliki proporsi unit usaha jasa-jasa sebesar $4,52 \%$ per tahun 2011, di mana prosentase ini merupakan peringkat ke-5 dari 10 UMKM sektor ekonomi bidang lainnya [1].

UMKM mempunyai peran penting dan strategis dalam pembangunan ekonomi nasional. Selama ini UMKM telah memberikan kontribusi pada Produk Domestik Bruto (PBD) sebesar $57-60 \%$ dan tingkat penyerapan tenaga kerja sekitar 97\% dari seluruh tenaga kerja nasional. Selama tahun 2011 sampai 2012 terjadi pertumbuhan pada UMKM serta penurunan pada usaha besar. Bila pada tahun 2011, usaha besar mencapai $41,95 \%$ tahun berikutnya hanya $40,92 \%$, turun sekitar $1,03 \%$. Pada UMKM terjadi sebaliknya. Bila usaha menengah pada tahun 2011 hanya 13,46\%, pada tahun 2012 mencapai 13,59\%. Ada peningkatan sebesar $0,13 \%$.

Pada umumnya UMKM bertempat/ berlokasi di lingkungan padat penduduk atau industri rumahan, di mana keberadaannya belum tersosialisasikan secara baik (tidak langsung bisa diketahui oleh masyarakat umum di luar lingkungan tersebut). Kondisi ini menyebabkan keberadaan lokasi UMKM menjadi tidak tersosialisasikan dengan baik kepada masyarakat. Di sisi lain, perkembangan teknologi peta digital yang ada saat ini sudah banyak diintegrasikan penggunaannya dalam berbagai perangkat seperti smartphone. Dengan peta digital saat ini, pengguna smartphone dimungkinkan untuk bisa melihat berbagai lokasi dari suatu obyek di seluruh dunia, termasuk rute untuk mencapainya. Pemanfaatan teknologi peta digital ini erat kaitannya dengan perkembangan teknologi Global Positioning System (GPS). Hampir semua smartphone saat ini sudah memiliki GPS sehingga memudahkan pengguna dalam menggunakan layanan peta digital. Banyak pengembangan aplikasi android yang memanfaatkan teknologi GPS dan peta digital tersebut. Ikhsan (2015) telah melakukan penelitian dengan pemanfaatan teknologi GPS pada smartphone android untuk memonitor kerusakan jalan di Kota Bogor berdasarkan laporan dari masyarakat dengan teknik Geotagging [2].

Berdasarkan latar belakang tersebut, pada penelitian ini dibangun aplikasi sebaran lokasi jasa UMKM di Kota Bogor berbasis android dengan Metode Location Based Services (LBS) dan Formula Haversine. Metode LBS digunakan untuk menentukan lokasi pengguna aplikasi dengan memanfaatkan teknologi GPS pada smartphone, sedangkan Formula Haversine digunakan untuk mengukur jarak lokasi pengguna aplikasi terhadap lokasi suatu jasa. Faundra, dkk (2016) telah memanfaatkan Metode LBS ini pada pembuatan aplikasi android untuk pencarian lokasi UKM (Usaha Kecil Menengah) di Wilayah Tembalang, Semarang [3]. Output dari penelitian ini adalah sebuah aplikasi android yang dapat digunakan oleh masyarakat untuk melihat sebaran lokasi jasa UMKM di Kota Bogor dan perkiraan jarak lokasi jasa tersebut dari pengguna aplikasi. 


\section{METODE PENELITIAN}

Metode yang digunakan pada penelitian ini meliputi enam langkah utama untuk mencapai target luaran penelitian yang diharapkan, yaitu studi literatur, pengumpulan data, analisis, perancangan, pembuatan program aplikasi, dan pengujian dengan Metode Blackbox. Metodologi pada penelitian ini diperlihatkan pada Gambar 1.

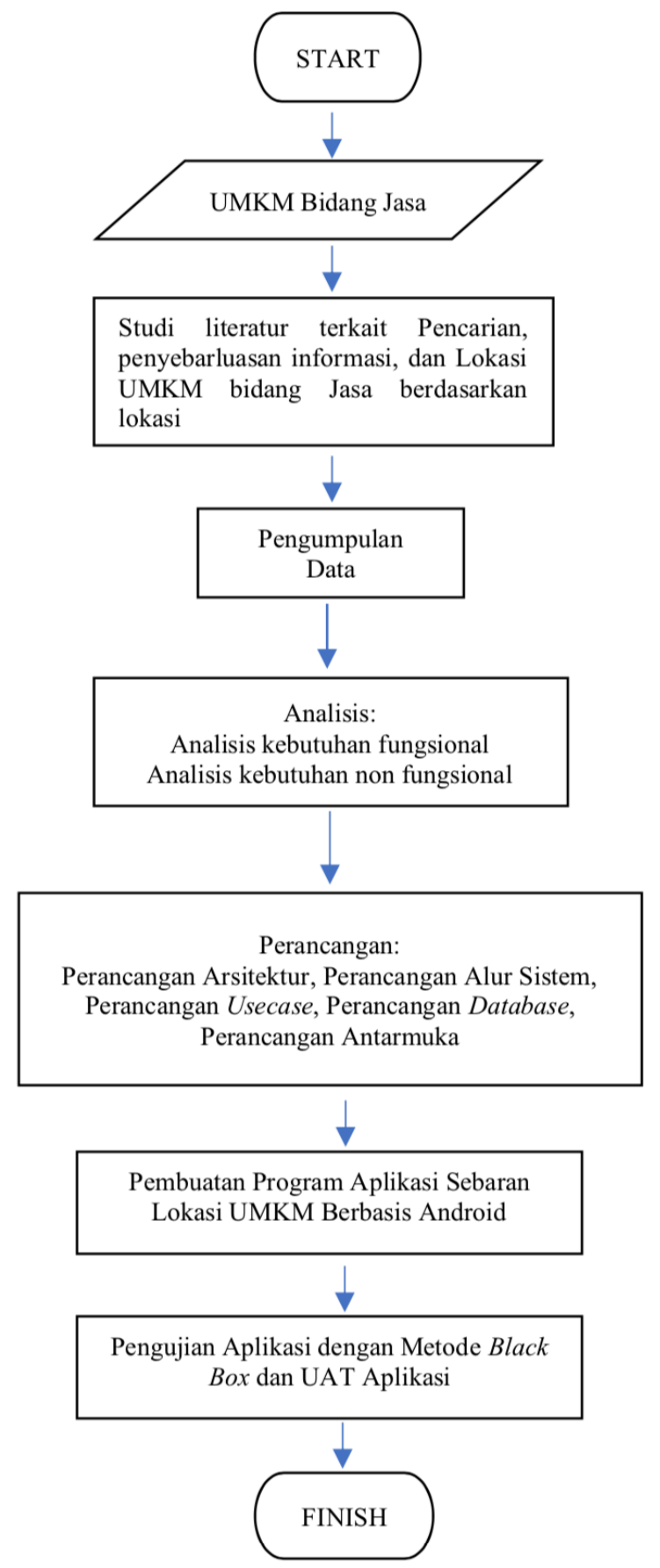

Gambar 1. Metode Penelitian

\section{a. Studi Literatur}

Pada tahapan ini dilakukan kegiatan berupa pencarian referensi yang relevan terkait dengan penelitian yang sedang dilakukan. Sumber literatur yang digunakan berasal dari buku, jurnal, prosiding, dan penelitian terkait lainnya yang sudah dilakukan. Studi literatur ini 
tentunya bisa memperkuat kualitas penelitian yang akan dilakukan.

\section{b. Pengumpulan Data}

Pada tahapan ini dilakukan pengumpulan data yang relevan dan terkait dengan rencana penelitian ini, yaitu data UMKM, kriteria UMKM, beberapa contoh lokasi UMKM, dan data lainnya. Data yang digunakan adalah data yang diperoleh dari observasi secara langsung di lapangan yaitu data lokasi dan data profil UMKM bidang jasa dan memberikan titik koordinat pada lokasi jasa UMKM yang disurvei.

\section{c. Analisis Kebutuhan}

Pada tahap ini dilakukan penentuan kebutuhan fungsional dan non fungsionalnya. Kebutuhan fungsional adalah kebutuhan yang langsung terkait dengan kemampuan/ operasional sistem, bagaimana sistem harus bereaksi pada input tertentu dan bagaimana perilaku sistem pada situasi tertentu. Sedangkan kebutuhan non fungsional terkait dengan properti perilaku sistem itu sendiri. Pada tahap ini dilakukan penentuan kebutuhan fungsional dan non fungsionalnya. Kebutuhan fungsional adalah kebutuhan yang langsung terkait dengan kemampuan/operasional sistem, bagaimana sistem harus bereaksi pada input tertentu dan bagaimana perilaku sistem pada situasi tertentu. Sedangkan kebutuhan non fungsional terkait dengan properti perilaku sistem itu sendiri. Selain itu, analisis juga dilakukan terhadap model LBS dan juga Haversine, bagaimana kedua metode tersebut bersinergi untuk dapat memetakan lokasi pengguna aplikasi terhadap jarak lokasi jasa di sekitar pengguna aplikasi.

\section{d. Perancangan}

Pada tahap ini dilakukan proses perancangan desain menggunakan Object Oriented Design (OOD) yang digambarkan dengan UML dan perancangan antar muka untuk aplikasi berbasis Android [4]. Beberapa model perancangan yang akan dilakukan untuk aplikasi sebaran lokasi jasa UMKM di Kota Bogor berbasis android ini adalah Use Case Diagram, Activity Diagram, Sequence Diagram, dan Deployment Diagram. Di samping itu, pada tahapan perancangan ini juga dilakukan perancangan antarmuka atau mockup aplikasi. Mockup aplikasi ini dirancang berdasarkan desain logis yang telah dilakukan sebelumnya. Perancangan mockup adalah perancangan model antarmuka (interface) sistem yang akan dikembangkan pada pembuatan program aplikasi berbasis android.

\section{e. Pembuatan Program Aplikasi}

Pada tahapan ini, dilakukan pembuatan program aplikasi berdasarkan rancangan yang telah dibuat sebelumnya. Aplikasi dibuat dengan berbasis android menggunakan Android Studio sebagai IDE-nya (Integrated Development Environment) [5]. Bahasa pemrograman utama pada pembuatan aplikasi android ini adalah Java. Pada pembuatan aplikasi android sebaran lokasi jasa UMKM ini, diimplementasikan Metode LBS dan Formula Haversine. Metode LBS digunakan untuk memetakkan lokasi pengguna aplikasi sesuai dengan data koordinat lokasi smartphone, sedangkan Formula Haversine digunakan untuk mengukur jarak lokasi pengguna terhadap lokasi jasa UMKM [6].

\section{f. Pengujian}

Setelah aplikasi selesai dibuat, tahapan selanjutnya dilakukan pengujian aplikasi. Pengujian dilakukan dengan Metode Black Box. Metode Black Box adalah sebuah metode pengujian terhadap fungsionalitas dari aplikasi dengan mengutamakan respon masukan dan keluarannya [7]. 


\section{HASIL DAN PEMBAHASAN}

\section{a. Pengumpulan Data}

Data yang digunakan pada penelitian ini adalah data hasil survei ke lokasi UMKM di Kota Bogor. Survei dilakukan selama dua hari dengan jumlah titik survei adalah 70 lokasi UMKM yang tersebar di Kota Bogor. Survei dilakukan untuk pencarian informasi mengenai profil singkat dari jasa UMKM beserta titik koordinat lokasi UMKM. Profil UMKM yang disurvei meliputi nama UMKM, alamat, nama pemilik, kategori, kontak, dan nilai aset. Pada Tabel 1 diperlihatkan contoh data hasil survei lokasi UMKM.

Tabel 1. Data Hasil Survei Lokasi UMKM

\begin{tabular}{|c|c|c|c|c|c|}
\hline NO & NAMA JASA & ALAMAT & $\begin{array}{l}\text { KATEGORI } \\
\text { JASA }\end{array}$ & LATITUDE & $\begin{array}{l}\text { LONGITU } \\
\text { DE }\end{array}$ \\
\hline 1 & Parjaya Photo copy & $\begin{array}{l}\text { Jl. Sukadamai No,5 Tanah } \\
\text { Sareal, Kota Bogor }\end{array}$ & Teknologi & -6.33129 & 106,47179 \\
\hline 2 & De Karedoxs & $\begin{array}{l}\text { Jl. Angsana No 5, Suka damai, } \\
\text { Tanah Sareal, Kota Bogor }\end{array}$ & $\begin{array}{l}\text { Makanan dan } \\
\text { Minuman }\end{array}$ & -6.33194 & 106.47226 \\
\hline 3 & $\begin{array}{l}\text { Er.De queen Rental } \\
\text { GPS }\end{array}$ & $\begin{array}{l}\text { Jl. Perikanan Darat No 6, Kota } \\
\text { Bogor }\end{array}$ & Teknologi & -6.34124 & 106.47149 \\
\hline 4 & Bakso AA & $\begin{array}{l}\text { J1. Tentara Pelajar No 20, Kota } \\
\text { Bogor }\end{array}$ & $\begin{array}{l}\text { Makanan dan } \\
\text { Minuman }\end{array}$ & -6.34259 & 106.47168 \\
\hline 5 & Prima Olshop & $\begin{array}{l}\text { Jl. Ciremai Ujung, Bantar Jati, } \\
\text { Bogor Utara, Kota Bogor }\end{array}$ & Fashion & -6.34313 & 106.48156 \\
\hline 6 & PB Hamdah & Jl. Raya Cilebut, Kota Bogor & Pertukangan & -6.32539 & 106.47564 \\
\hline 7 & Ceremai Teknik & Jl.Ceremai Ujung, Kota Bogor & Pertukangan & -6.335114 & 106.47594 \\
\hline 8 & King Laundry & $\begin{array}{l}\text { J1. Taman Cimanggu Raya No } \\
23 \text {, Kota Bogor }\end{array}$ & Kebersihan & -6.33537 & 106.46583 \\
\hline 9 & Seript Institute & $\begin{array}{l}\text { Jl.Budi Agung, Tanah Sareal, } \\
\text { Kota Bogor }\end{array}$ & Pendidikan & -6.33162 & 106.47360 \\
\hline 10 & Aku Cuci Laundry & $\begin{array}{l}\text { Jl. Pakuan } \quad \text { No } 43 \\
\text { Baranangsiang, Kota Bogor }\end{array}$ & Kebersihan & -6.36087 & 106.48486 \\
\hline 11 & Jason Production & $\begin{array}{l}\text { J1. Rambutan No 32, Kota } \\
\text { Bogor }\end{array}$ & Fashion & -637090 & 106.49152 \\
\hline 12 & $\begin{array}{l}\text { HOTDOUGH } \\
\text { BOOTH }\end{array}$ & Jl. Manunggal, Kota Bogor & $\begin{array}{l}\text { Makanan dan } \\
\text { Minuman }\end{array}$ & -6.34595 & 106.47103 \\
\hline 13 & Bintang Motor & $\begin{array}{l}\text { Jl. Ahmad Sobana No. } 34 \text { Tegal } \\
\text { Gundil, Bogor Utara, Kota } \\
\text { Bogor }\end{array}$ & Kendaraan & $-6,5812320$ & 106,8114780 \\
\hline 14 & Bogor Laundry & $\begin{array}{l}\text { Jl. Bangbarung Raya No.57 } \\
\text { Tegal Gundil, Bogor Utara, } \\
\text { Kota Bogor }\end{array}$ & Fashion & $-6,5809688$ & 106,8101845 \\
\hline 15 & $\begin{array}{l}\text { Paramita } \\
\text { House }\end{array}$ & $\begin{array}{l}\text { Bantarjati, Bogor Utara, Kota } \\
\text { Bogor, Jawa Barat } 16153\end{array}$ & Event / Acara & $-6,5696380$ & 106,8122150 \\
\hline
\end{tabular}

\section{b. Analisis}

Analisis dilakukan terhadap kebutuhan fungsional dan non fungsional aplikasi. Kebutuhan fungsional aplikasi terdiri dari:

1. Fungsi pendaftaran akun

2. Fungsi login

3. Fungsi logout

4. Fungsi melihat sebaran lokasi UMKM

5. Fungsi manajemen akun

6. Fungsi manajemen UMKM

7. Fungsi manajemen notifikasi 
Sedangkan analisis kebutuhan non fungsional yang dilakukan meliputi:

1. Operasional, di mana syarat minimum sistem operasi yang dapat menjalankan aplikasi ini adalah versi Android Jelly Bean 4.1 sampai dengan versi terbaru (android pie)

2. Keamanan, di mana aplikasi menggunakan otentikasi username dan password untuk mengakses aplikasi sesuai dengan levelnya, apakah sebagai pemilik UMKM (penyedia layanan), sebagai pencari jasa atau calon pengguna layanan UMKM, maupun sebagai pengguna umum.

\section{c. Perancangan}

\section{Perancangan arsitektur sistem}

Arsitektur aplikasi ini mengacu pada model proses arsitektur client-server. Model client-server menunjukkan bahwa client dalam hal ini aplikasi, akan aktif mengirim dan menerima data dari layanan yang disediakan oleh server. Aplikasi ini memanfaatan infrastruktur teknologi Global Positioning System (GPS) dan Internet Service Provider (ISP) yang digunakan untuk menentukan lokasi (titik koordinat) pengguna dan lokasi UMKM. Adapun Google Maps API digunakan sebagai basis layer peta pada aplikasi. Aplikasi akan berkomunikasi dengan database menggunakan JSON String untuk melakukan perubahan dan pengambilan data pada database. JSON String didapatkan dari penggunaan Web Services Application Programming Interface (API) yang telah tersedia untuk pemerosesan data pada database sistem.

Setelah proses positioning, informasi lokasi UMKM yang didapatkan melalui $W e b$ Services API selanjutnya akan diproses untuk menentukan jarak antara pencari jasa dan penyedia jasa menggunakan formula Haversine. Setelah didapatkan jarak maka akan ditampilkan informasi UMKM dan lokasinya dengan menggunakan Google Maps API. Analisis perancangan arsitektur sistem yang digunakan pada penelitian ini dapat dilihat pada Gambar 2.

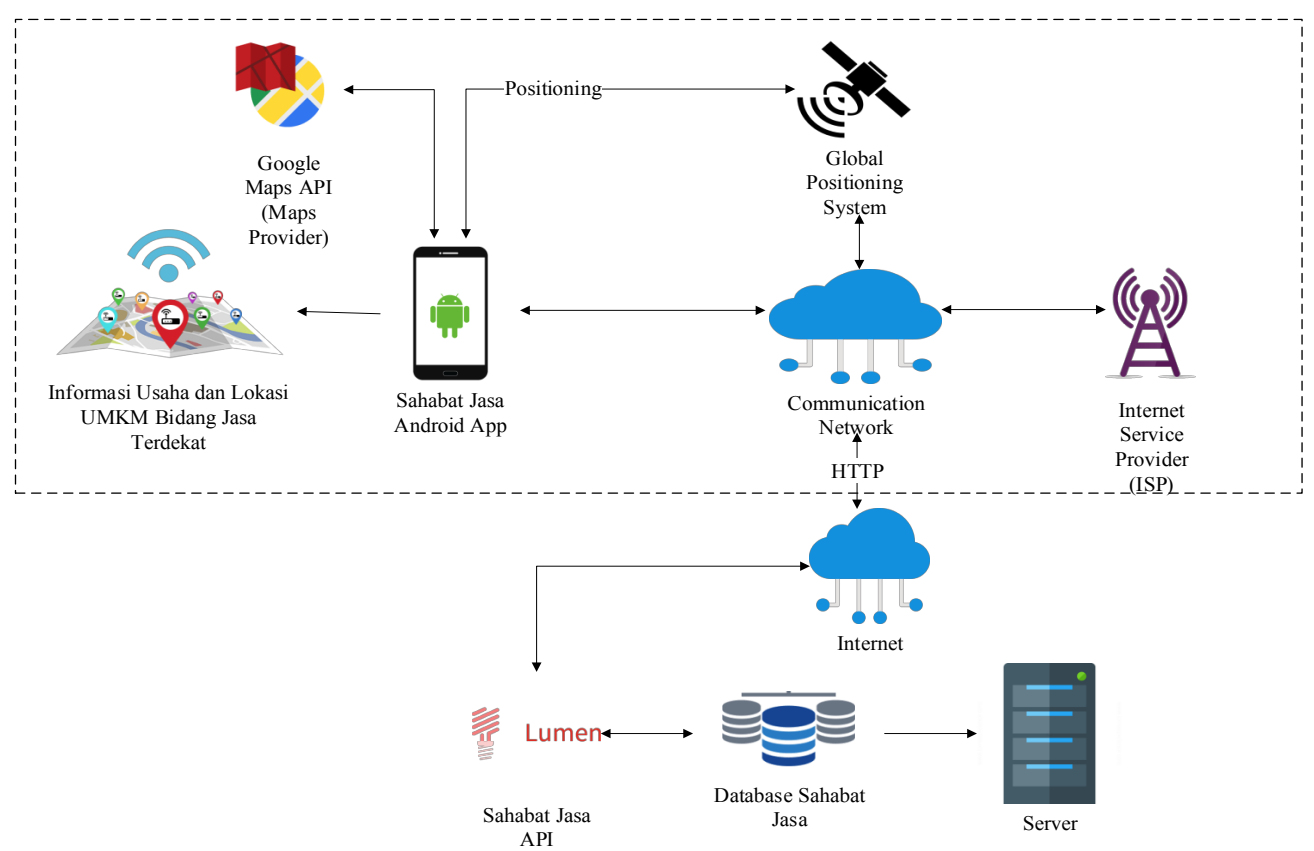

Gambar 2. Analisis Arsitektur Sistem

\section{Diagram Konteks}

Diagram konteks merupakan diagram yang menggambarkan proses bisnis suatu sistem yang dibuat. Proses bisnis mendefinisikan kegiatan pelaku (aktor) terhadap sistem. Diagram 
konteks pada penelitian ini ditunjukkan pada Gambar 3.

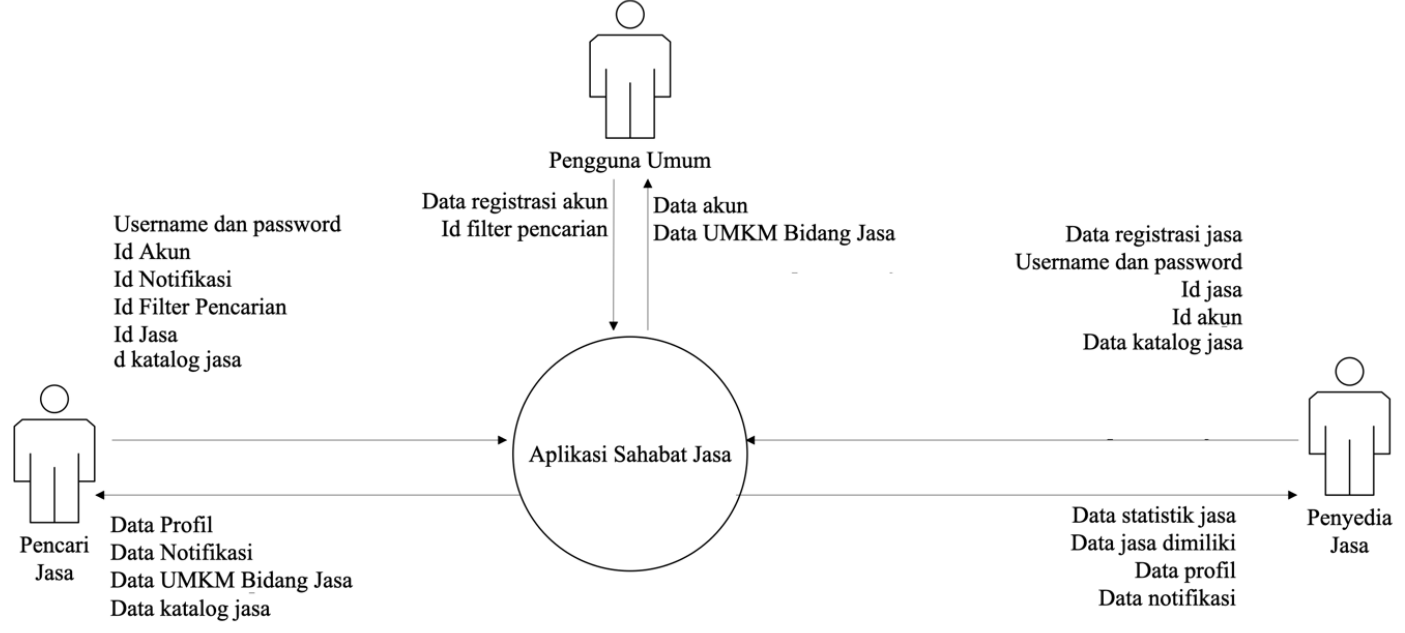

Gambar 3. Diagram Konteks

\section{Diagram Aktivitas}

Diagram aktivitas menggambarkan berbagai alir aktivitas yang terdapat pada sistem yang sedang dirancang, bagaimana masing-masing alir aktivitas berawal, kondisi yang mungkin terjadi dan bagaimana masing-masing alir aktivitas tersebut berakhir. Diagram aktivitas yang dibuat meliputi seluruh fungsionalitas aplikasi yang sudah dibahas pada bagian analisis kebutuhan fungsional. Contoh diagram aktivitas yang dibuat adalah:

1. Diagram aktivitas login

Diagram ini menggambarkan alir aktivitas pencari atau penyedia jasa untuk masuk kedalam sistem, sehingga dapat melakukan aktivitas yang tidak dapat dilakukan oleh pengguna umum. Diagram aktivitas Login ditunjukkan oleh Gambar 4.

2. Diagram aktivitas pencarian jasa lokasi UMKM

Diagram ini menggambarkan alir aktivitas pencari jasa atau pengguna umum untuk mencari jasa dengan filter kriteria pencarian yang telah disediakan oleh sistem, selanjutnya sistem akan menentukan lokasi pengguna, menghitung jarak lokasi pencari dan jasa yang dicari menggunakan Formula Haversine dan mengurutkan informasi usaha dan lokasi jasa berdasarkan jarak lokasi yang terdekat. Diagram aktivitas Mencari Jasa ditunjukkan pada Gambar 5.

\section{Diagram Sekuensial}

Diagram Sekuensial meggambarkan interaksi antar objek yang terdapat di dalam maupun di lingkungan sekitar sistem. Interaksi dalam Sequence Diagram digambarkan dengan message dan waktu interaksi. Diagram sekuensial terdiri dari dimensi vertikal (waktu) dan dimensi horizontal (objek-objek terkait). Contoh diagram sekuensial yang dibuat adalah:

1. Diagram sekuensial login

Diagram Sekuensial Login menggambarkan proses pencari atau penyedia jasa dengan sistem untuk dapat masuk kedalam sistem. Diagram Sekuensial Login ditunjukkan oleh Gambar 6.

2. Diagram sekuensial pencarian jasa UMKM

Diagram Sekuensial Pencarian Jasa menggambarkan proses pencari dan pengguna umum dengan sistem untuk mencari jasa sesuai kriteria pencarian yang telah disediakan oleh sistem. Diagram Sekuensial Pencarian Jasa diperlihatkan pada Gambar 7. 


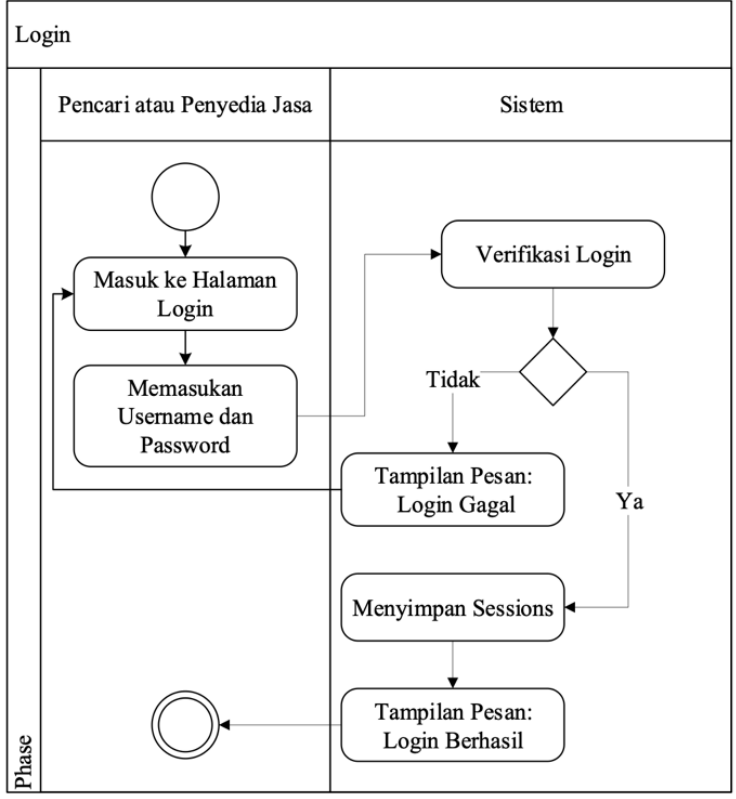

Gambar 4. Diagram Aktivitas Login

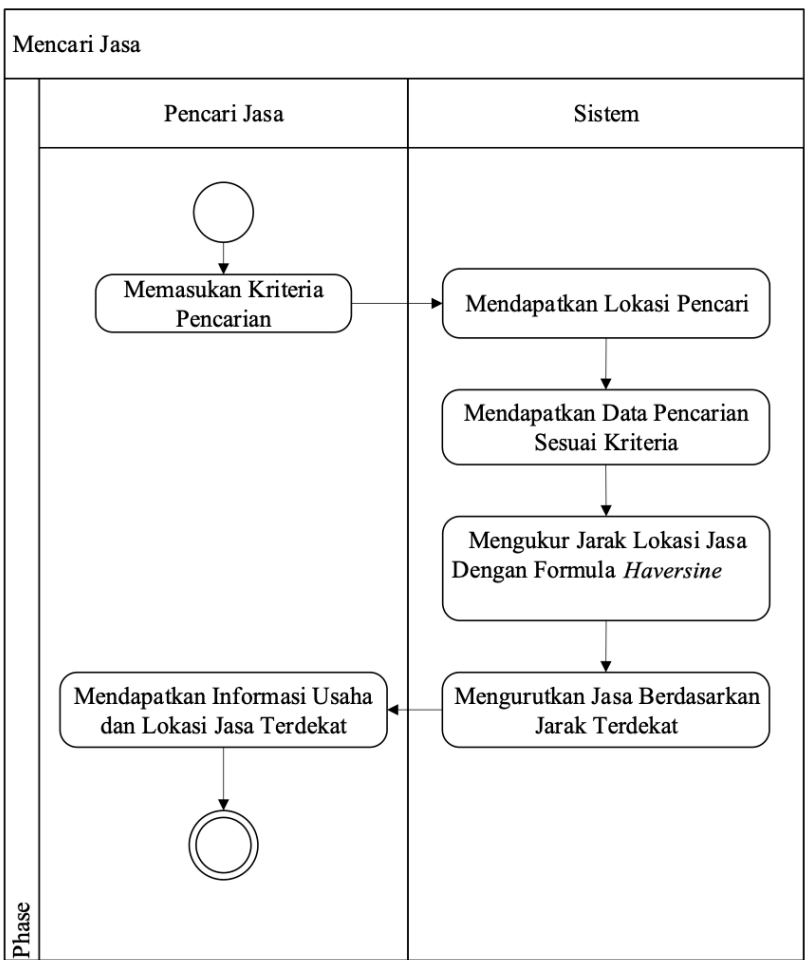

Gambar 5. Diagram Aktivitas Pencarian Jasa UMKM

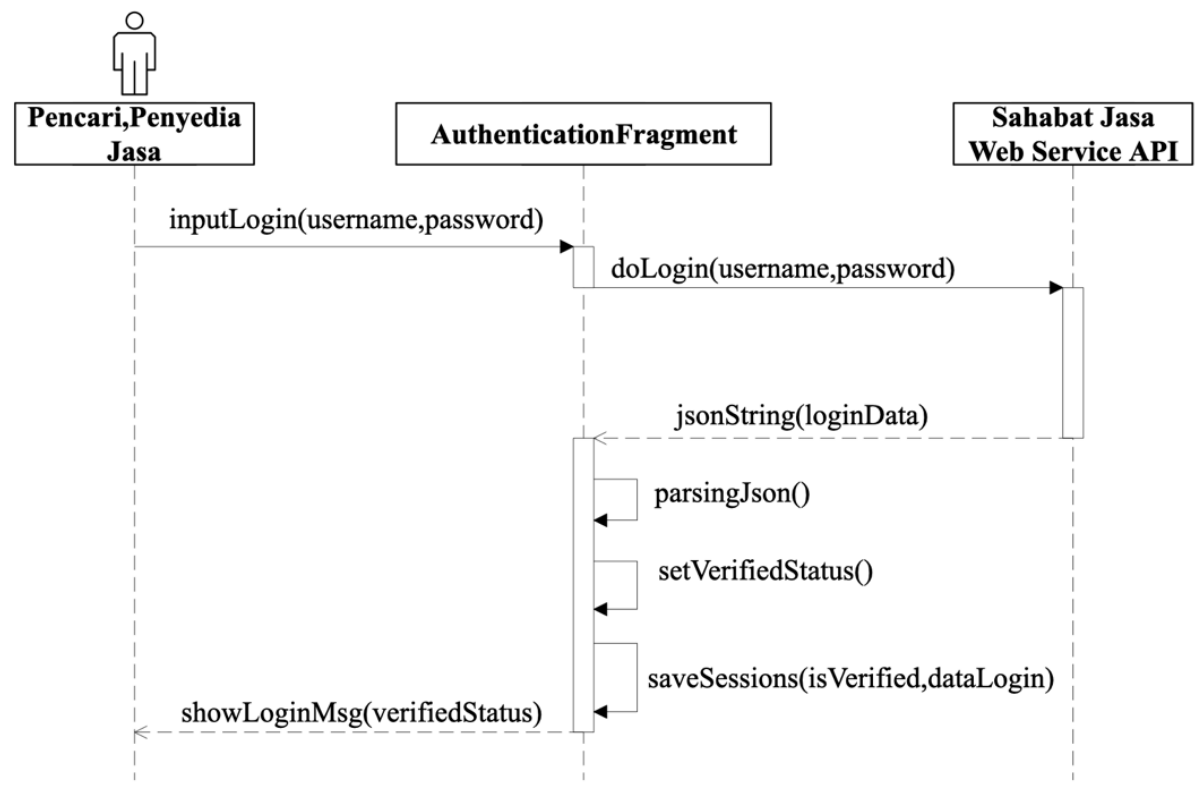

Gambar 6. Diagram Sekuensial Login 


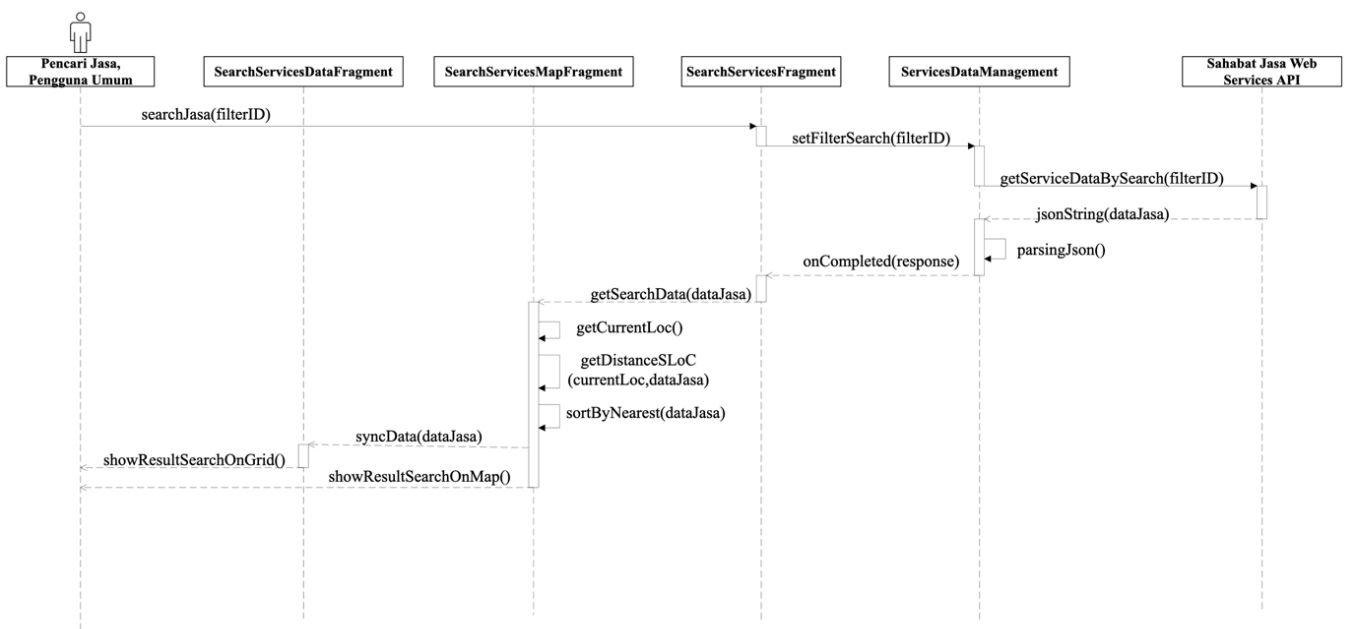

Gambar 7. Diagram Sekuensial Pencarian Jasa UMKM

\section{Diagram Komponen}

Diagram komponen menggambarkan organisasi dan ketergantungan diantara kumpulan komponen dalam sebuah sistem. Diagram komponen yang terdapat pada penelitian ini ditunjukkan oleh Gambar 8.

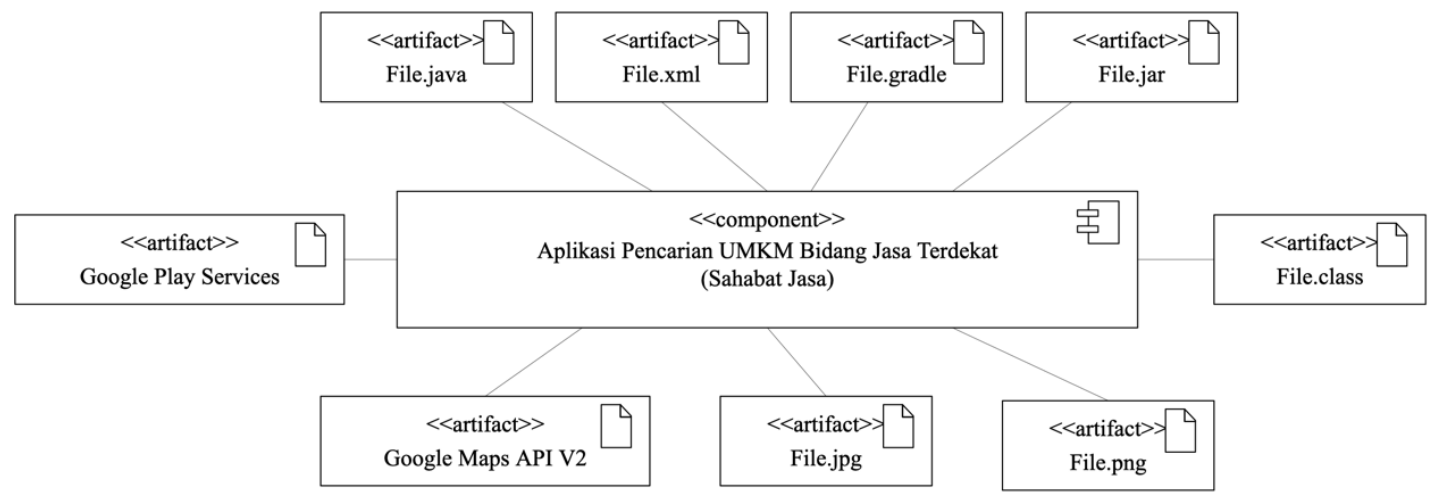

Gambar 8. Diagram Komponen

\section{Deployment Diagram}

Deployment Diagram menggambarkan konfigurasi antar setiap komponen dalam proses eksekusi sistem. Deployment Diagram pada penelitian ini ditunjukkan oleh Gambar 9.
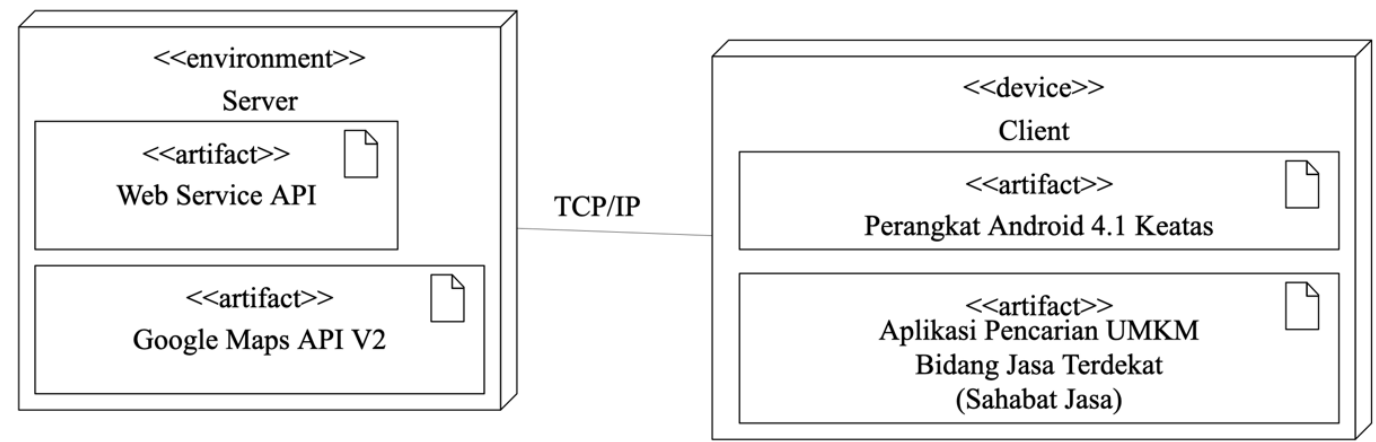

Gambar 9. Deployment Diagram 


\section{d. Pembuatan Aplikasi}

\section{Pembuatan Form Login}

Login merupakan implementasi desain sistem login yang digunakan pencari atau penyedia jasa untuk masuk kedalam sistem. Implementasi login dilakukan dengan menyediakan form login, tombol bantuan lupa password, daftar akun/registrasi dan melewati tahap login untuk masuk sistem sebagai pengguna umum. Implementasi login ditunjukkan oleh Gambar 10.

\section{Pembuatan Form Registrasi Akun}

Registrasi akun digunakan sebagai fitur untuk mendaftarkan data profil dari pengguna, baik pengguna sebagai pencari jasa maupun pengguna sebagai penyedia jasa. Registrasi akun ini dibuat dalam dua model, yaitu registrasi akun dengan otentikasi API Google dan registrasi secara biasa. Pada Gambar 11 diperlihatkan implementasi registrasi akun secara biasa dan dengan API Google.
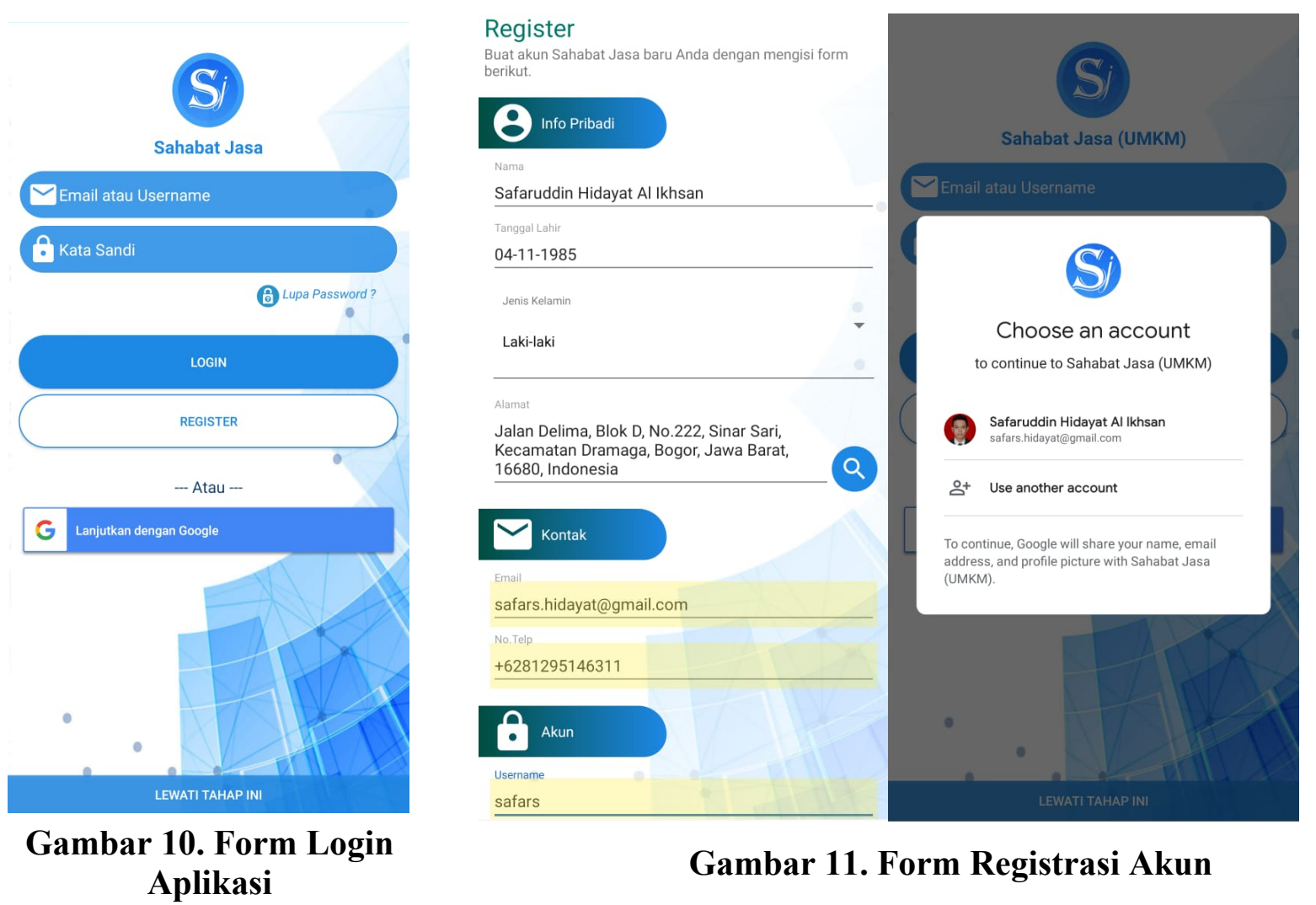

Gambar 11. Form Registrasi Akun

\section{Pembuatan Dashboard/Beranda}

Dashboard atau beranda merupakan implementasi desain sistem halaman utama bagi pencari jasa dan pengguna umum dimana terdapat tampilan field pencarian jasa, slider jasa terbaru, kategori jasa, jasa terpopuler dan jasa terdekat. Implementasi Home ditunjukkan oleh Gambar 12. 


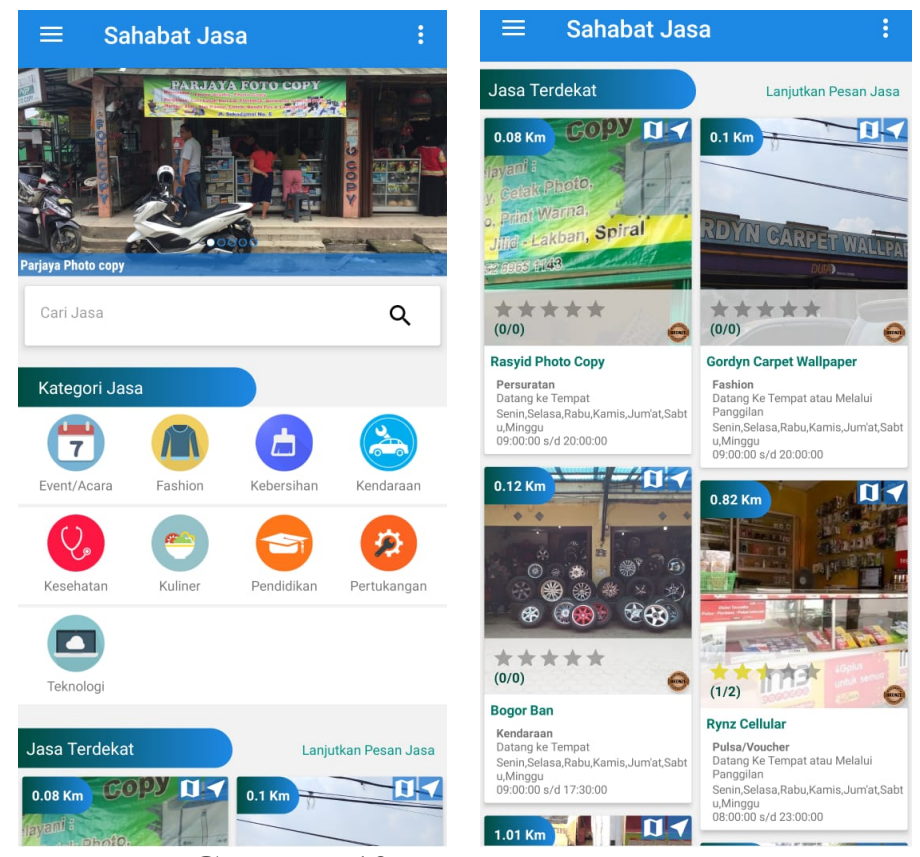

Gambar 12. Halaman Beranda

\section{Pembuatan Form Pencarian Jasa (Sebaran Lokasi UMKM)}

Pencarian Jasa merupakan implementasi desain sistem pencarian jasa yang digunakan oleh pengguna umum maupun pencari jasa. Implementasi pencarian jasa memiliki field untuk memasukan kata kunci, menggunakan filter kriteria pencarian dan tampilan hasil pencarian yang terbagi menjadi dua tabulasi yaitu map dan grid.

Implementasi pencarian jasa menggunakan metode LBS dan Formula Haversine. Pada Gambar 13 diperlihatkan implementasi Pencarian Jasa pada Apikasi Android.

\section{Pembuatan Form Manajemen Akun}

Manajemen akun merupakan implementasi desain sistem yang digunakan oleh pengguna sistem yang memiliki akun untuk mengedit dan menonaktifkan akun dirinya sendiri. Implementasi akun ditunjukkan oleh Gambar 14.

\section{e. Implementasi Penggunaan LBS dan Formula Haversine}

Aplikasi sebaran lokasi UMKM ini menggunakan Location Based Services (LBS) dan Formula Haversine. Metode LBS ini digunakan untuk menentukan lokasi pengguna jasa pada saat mencari jasa. Metode LBS pada aplikasi ini memanfaatkan infrastruktur teknologi GPS Provider dan Internet Service Provider (ISP) untuk menentukan titik koordinat pencari jasa. Penerapan pada aplikasi menggunakan fungsi yang terdapat pada Google Maps API untuk meminta koordinat lokasi saat ini dengan mengggunakan 2 Provider yang tersedia yaitu GPS dan ISP berikut potongan kode penerapan LBS pada aplikasi. Hasil penerapan LBS pada aplikasi ini diperlihatkan pada Gambar 15.

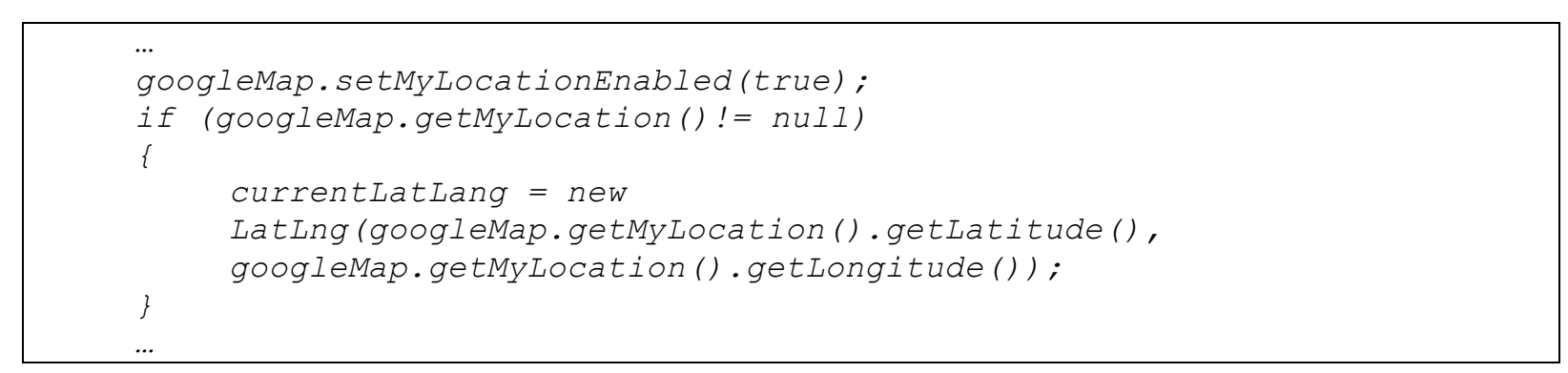




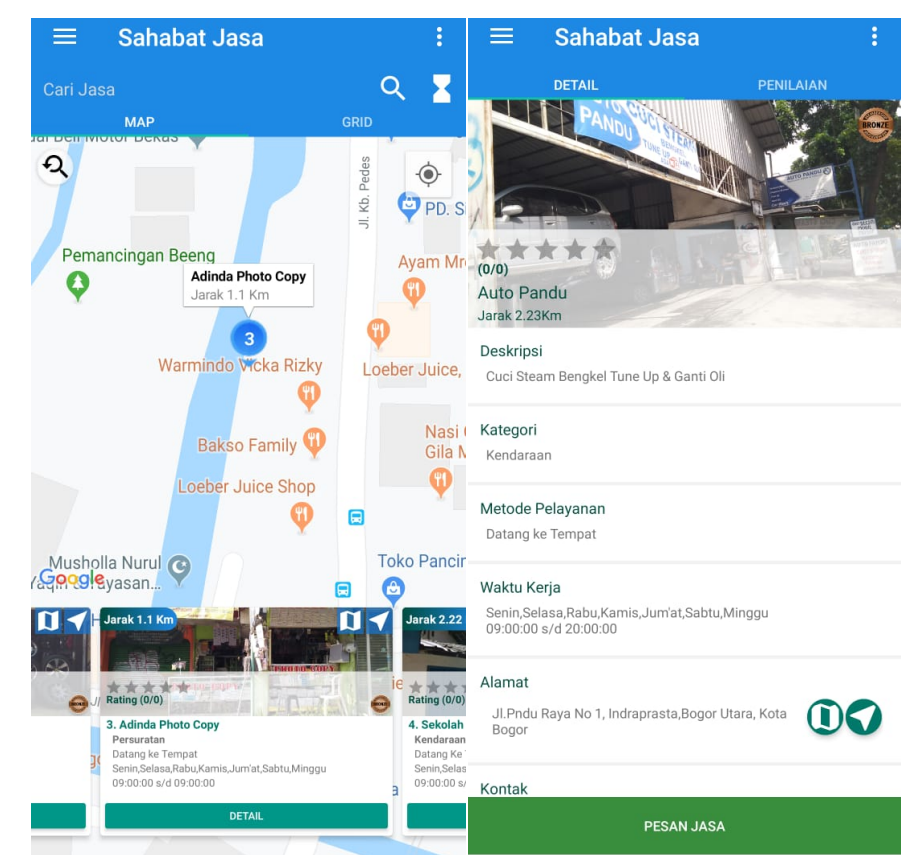

Gambar 13. Halaman Sebaran UMKM (Pencarian Jasa)
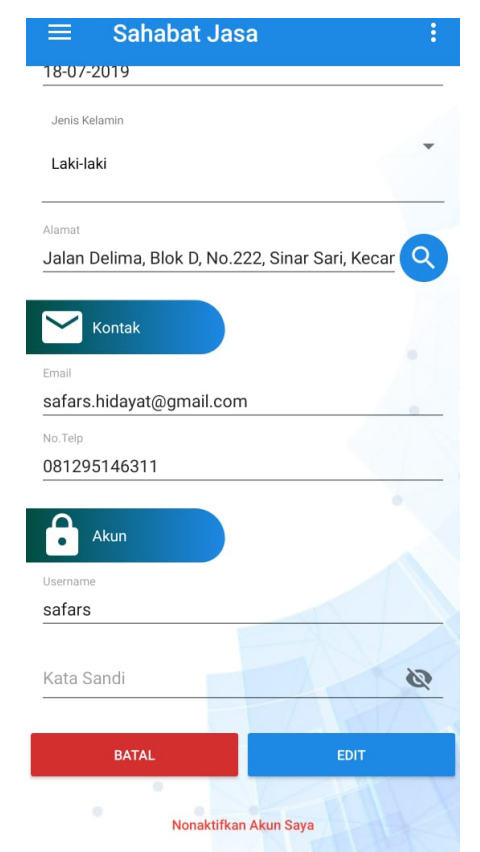

\section{Gambar 14. Form Manajemen}

Akun

Penerapan Formula Haversine pada aplikasi ini digunakan untuk menghitung jarak lokasi pengguna dengan lokasi suatu UMKM, di mana jarak yang diukur pada formula ini mengabaikan medan yang dihadapi dan hanya menarik garis lurus antara dua titik koordinat. Formulasi ini menggunakan persamaan Haversine sebagai dasar. Persamaan ini dapat digunakan untuk menghitung jarak lingkaran yang jauh antara dua titik. Hasil implementasi Formula Haversine pada aplikasi diperlihatkan pada Gambar 16.

Berikut adalah rumus dari Formula Haversine:

$$
\begin{aligned}
& \Delta \text { lat }=\text { lat } 2-\text { lat } 1 \\
& \Delta \text { long }=\text { long } 2-\text { long } 1 \\
& a=\sin ^{2}(\Delta \text { lat } / 2)+\cos (\text { lat } 1) \cdot \cos (\text { lat } 2) \cdot \sin ^{2}(\Delta \text { long } / 2) \\
& c=2 \cdot \operatorname{atan} 2(\sqrt{ } a, \sqrt{ }(1-a)) \\
& d=\text { R.c }
\end{aligned}
$$

Keterangan:

$\mathrm{R}=$ jari-jari bumi sebesar $6371(\mathrm{~km})$

$\Delta$ lat $=$ besaran perubahan latitude

$\Delta$ long $=$ besaran perubahan longitude

$\mathrm{c}=$ kalkulasi perpotongan sumbu

$\mathrm{d}=\operatorname{jarak}(\mathrm{km})$ 


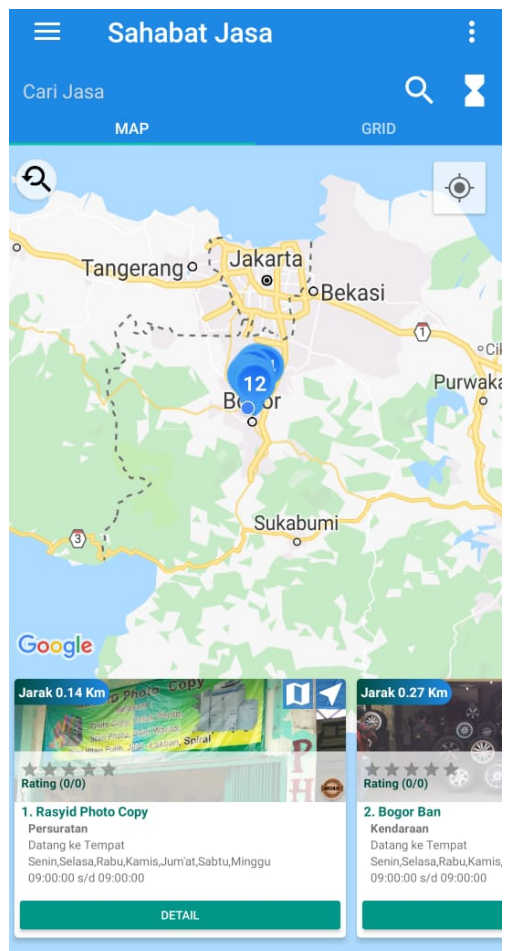

\section{Gambar 15. Penerapan Metode LBS}

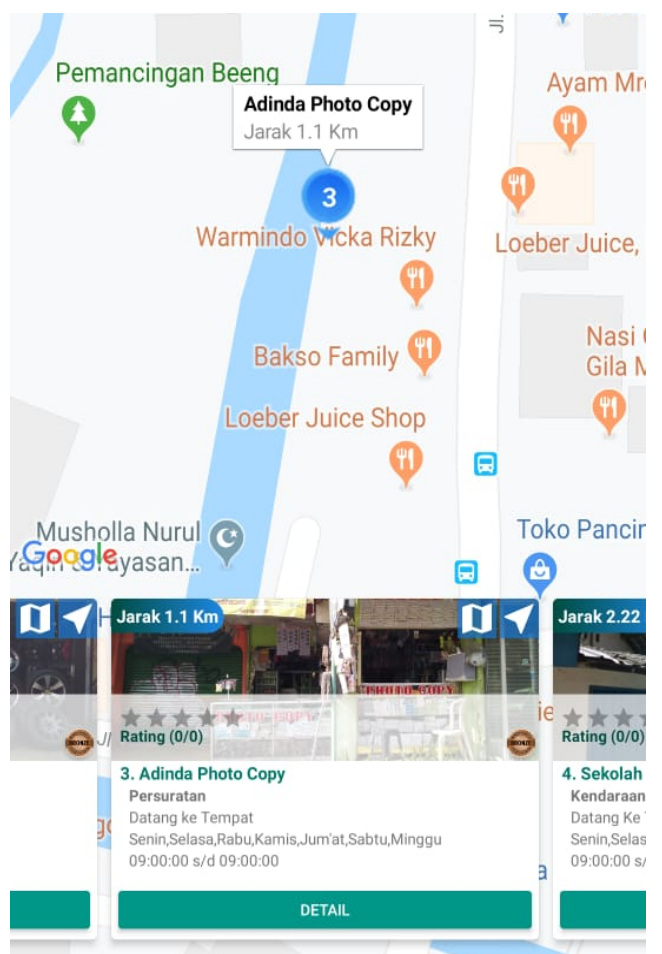

Gambar 16. Implementasi Formula Haversine pada Aplikasi

\section{f. Pengujian}

Pengujian dengan Metode Black Box dilakukan dengan melakukan pengujian validasi hasil yang dikeluarkan oleh aplikasi pada saat suatu perintah/ proses diberikan oleh pengguna. Pengujian Black Box pada aplikasi android sebaran UMKM ditunjukkan pada Tabel 2.

Tabel 2. Hasil Pengujian Aplikasi dengan Metode Black Box

\begin{tabular}{|c|c|c|c|c|c|}
\hline No & $\begin{array}{c}\text { Nama } \\
\text { Pengujian }\end{array}$ & $\begin{array}{l}\text { Input yang } \\
\text { Diberikan }\end{array}$ & Kondisi & $\begin{array}{l}\text { Output yang } \\
\text { diharapkan }\end{array}$ & kesimpulan \\
\hline \multirow[t]{2}{*}{1} & \multirow[t]{2}{*}{ Login } & \multirow[t]{2}{*}{$\begin{array}{l}\text { Username, } \\
\text { Password, Button } \\
\text { Login }\end{array}$} & $\begin{array}{l}\text { Server Tidak } \\
\text { Terhubung dan } \\
\text { Input Lengkap }\end{array}$ & $\begin{array}{l}\text { Menampilkan pesan } \\
\text { error }\end{array}$ & Berhasil \\
\hline & & & $\begin{array}{l}\text { Server } \\
\text { Terhubung dan } \\
\text { Input Lengkap }\end{array}$ & $\begin{array}{l}\text { Menampilkan pesan } \\
\text { sukses dan masuk } \\
\text { kedalam sistem }\end{array}$ & Berhasil \\
\hline \multirow[t]{2}{*}{2} & \multirow[t]{2}{*}{ Logout } & \multirow[t]{2}{*}{ Button Logout } & $\begin{array}{l}\text { Server Tidak } \\
\text { Terhubung }\end{array}$ & $\begin{array}{l}\text { Menampilkan pesan } \\
\text { error }\end{array}$ & Berhasil \\
\hline & & & $\begin{array}{l}\text { Server } \\
\text { Terhubung }\end{array}$ & $\begin{array}{l}\text { Menampilkan pesan } \\
\text { sukses dan keluar } \\
\text { dari sistem ke } \\
\text { tampilan home }\end{array}$ & Berhasil \\
\hline \multirow[t]{2}{*}{3} & \multirow[t]{2}{*}{ Daftar Akun } & \multirow{2}{*}{$\begin{array}{l}\text { Data form } \\
\text { infromasi } \\
\text { pengguna, Button } \\
\text { submit }\end{array}$} & $\begin{array}{l}\text { Server Tidak } \\
\text { Terhubung }\end{array}$ & $\begin{array}{l}\text { Menampilkan pesan } \\
\text { error }\end{array}$ & Berhasil \\
\hline & & & $\begin{array}{l}\text { Server } \\
\text { Terhubung }\end{array}$ & $\begin{array}{l}\text { Menampikan pesan } \\
\text { sukses, dan } \\
\text { pengguna dapat } \\
\text { login dengan akun }\end{array}$ & Berhasil \\
\hline
\end{tabular}




\begin{tabular}{|c|c|c|c|c|c|}
\hline No & $\begin{array}{c}\text { Nama } \\
\text { Pengujian }\end{array}$ & $\begin{array}{l}\text { Input yang } \\
\text { Diberikan }\end{array}$ & Kondisi & $\begin{array}{l}\text { Output yang } \\
\text { diharapkan }\end{array}$ & kesimpulan \\
\hline \multirow[t]{2}{*}{4} & \multirow[t]{2}{*}{$\begin{array}{l}\text { Halaman } \\
\text { Home }\end{array}$} & \multirow[t]{2}{*}{ Button Home } & $\begin{array}{l}\text { Server Tidak } \\
\text { Terhubung }\end{array}$ & $\begin{array}{l}\text { yang telah terdaftar } \\
\text { Data home tidak } \\
\text { muncul }\end{array}$ & Berhasil \\
\hline & & & $\begin{array}{l}\text { Server } \\
\text { Terhubung }\end{array}$ & Data home muncul & Berhasil \\
\hline \multirow[t]{2}{*}{5} & \multirow[t]{2}{*}{ Pencarian Jasa } & \multirow[t]{2}{*}{$\begin{array}{l}\text { Data filter } \\
\text { kriterian pencarian } \\
\text { jasa, Button } \\
\text { Search }\end{array}$} & $\begin{array}{l}\text { Server Tidak } \\
\text { Terhubung } \\
\text { Server } \\
\text { Terhubung dan } \\
\text { GPS aktif }\end{array}$ & $\begin{array}{l}\text { Data pencarian jasa } \\
\text { tidak muncul } \\
\text { Data pencarian jasa } \\
\text { tidak muncul }\end{array}$ & Berhasil \\
\hline & & & $\begin{array}{l}\text { Server } \\
\text { Terhubung dan } \\
\text { GPS tidak aktif }\end{array}$ & $\begin{array}{l}\text { Data pencarian jasa } \\
\text { tidak muncul, } \\
\text { muncul peringatan } \\
\text { untuk aktifkan GPS }\end{array}$ & Berhasil \\
\hline \multirow[t]{2}{*}{6} & \multirow[t]{2}{*}{$\begin{array}{l}\text { Manajemen } \\
\text { Jasa }\end{array}$} & \multirow{2}{*}{$\begin{array}{l}\text { Data form Jasa, } \\
\text { Button submit, } \\
\text { Button delete }\end{array}$} & $\begin{array}{l}\text { Server Tidak } \\
\text { Terhubung }\end{array}$ & Muncul pesan error & Berhasil \\
\hline & & & $\begin{array}{l}\text { Server } \\
\text { Terhubung }\end{array}$ & $\begin{array}{l}\text { Muncul pesan } \\
\text { sukses }\end{array}$ & Berhasil \\
\hline \multirow[t]{2}{*}{7} & \multirow[t]{2}{*}{$\begin{array}{l}\text { Manajemen } \\
\text { Akun }\end{array}$} & \multirow{2}{*}{$\begin{array}{l}\text { Data form akun, } \\
\text { Button edit, Button } \\
\text { nonaktif }\end{array}$} & $\begin{array}{l}\text { Server Tidak } \\
\text { Terhubung }\end{array}$ & Muncul pesan error & Berhasil \\
\hline & & & $\begin{array}{l}\text { Server } \\
\text { Terhubung }\end{array}$ & $\begin{array}{l}\text { Muncul pesan } \\
\text { sukses }\end{array}$ & Berhasil \\
\hline \multirow[t]{2}{*}{8} & \multirow[t]{2}{*}{$\begin{array}{l}\text { Manajemen } \\
\text { Notifikasi }\end{array}$} & \multirow[t]{2}{*}{$\begin{array}{l}\text { Data notifikasi, } \\
\text { Button delete }\end{array}$} & $\begin{array}{l}\text { Server Tidak } \\
\text { Terhubung }\end{array}$ & Muncul pesan error & Berhasil \\
\hline & & & $\begin{array}{l}\text { Server } \\
\text { Terhubung }\end{array}$ & $\begin{array}{l}\text { Muncul pesan } \\
\text { sukses }\end{array}$ & Berhasil \\
\hline
\end{tabular}

\section{KESIMPULAN}

Kesimpulan dari penelitian ini adalah: (1) aplikasi sebaran lokasi UMKM telah dibangun dengan fungsionalitas seperti login aplikasi, pendaftaran akun, pencarian jasa UMKM, manajemen akun, manajemen layanan jasa, dan manajemen notifikasi, (2) penerapan Metode LBS dan Formula Haversine pada aplikasi ini telah berhasil digunakan untuk menentukan perhitungan jarak lokasi pengguna terhadap lokasi suatu jasa UMKM.

\section{DAFTAR PUSTAKA}

[1] I. Bank, Profil Bisnis Usaha Mikro, Kecil dan Menengah. Jakarta, 2015.

[2] S. H. Al-Ikhsan, P. Eosina, and I. S. Pratama, "APLIKASI MONITORING JALAN RUSAK KOTA BOGOR BERBASIS ANDROID MENGUNAKAN GEOTAGGING (STUDI KASUS: DINAS BINAMARGA KOTA BOGOR),” KREA-TIF, vol. 3, no. 2, p. 51, Nov. 2015.

[3] I. Faundra, R. Kridalukmana, and I. Pertiwi, "Aplikasi Pencari Lokasi Ukm Di Tembalang Menggunakan Location Based Service,” Jurnal Teknologi dan Sistem Komputer, vol. 4, p. 518 , Nov. 2016.

[4] S. Dharwiyanti and R. S. Wahono, “Pengantar Unified Modeling Language (UML),” Ilmu 
Komputer, pp. 1-13, 2003.

[5] A. Satyaputra, E. M. Aritonang, and S. Kom, Lets Build Your Android Apps with Android Studio. Elex Media Komputindo, 2016.

[6] Y. Yulianto, R. Ramadiani, and A. harsa kridalaksana, "Penerapan Formula Haversine Pada Sistem Informasi Geografis Pencarian Jarak Terdekat Lokasi Lapangan Futsal,” Informatika Mulawarman : Jurnal Ilmiah Ilmu Komputer, vol. 13, p. 14, Feb. 2018.

[7] S. Nidhra, "Black Box and White Box Testing Techniques - A Literature Review," International Journal of Embedded Systems and Applications, vol. 2, pp. 29-50, Jun. 2012. 